\title{
Evidence for multiple recombination events within foot-and-mouth disease viruses circulating in West Eurasia
}

Jamal, Syed Muhammad ; Nazem Shirazi, M; Ozyoruk, Fuat; Parlak, Unal; Normann, Preben; Belsham, Graham

Published in:

Transboundary and Emerging Diseases

Link to article, DOI:

10.1111/tbed.13433

Publication date:

2020

Document Version

Peer reviewed version

Link back to DTU Orbit

Citation (APA):

Jamal, S. M., Nazem Shirazi, M., Ozyoruk, F., Parlak, U., Normann, P., \& Belsham, G. (2020). Evidence for multiple recombination events within foot-and-mouth disease viruses circulating in West Eurasia. Transboundary and Emerging Diseases, 67(2), 979-993. https://doi.org/10.1111/tbed.13433

\section{General rights}

Copyright and moral rights for the publications made accessible in the public portal are retained by the authors and/or other copyright owners and it is a condition of accessing publications that users recognise and abide by the legal requirements associated with these rights.

- Users may download and print one copy of any publication from the public portal for the purpose of private study or research.

- You may not further distribute the material or use it for any profit-making activity or commercial gain

- You may freely distribute the URL identifying the publication in the public portal 
DR. SYED MUHAMMAD JAMAL (Orcid ID : 0000-0002-0768-4471)

PROF. GRAHAM J. BELSHAM (Orcid ID : 0000-0003-1187-4873)

Article type : Original Article

Title: Evidence for multiple recombination events within foot-and-mouth disease viruses circulating in West Eurasia

Running title: Recombination in FMDVs

Syed M. Jamal ${ }^{1}$, M. Nazem Shirazi ${ }^{2}$, Fuat Ozyoruk ${ }^{3}$, Unal Parlak ${ }^{3}$, Preben Normann ${ }^{4,5}$, Graham J. Belsham ${ }^{4,5 *}$

${ }^{1}$ Department of Biotechnology, University of Malakand, Pakistan

${ }^{2}$ Iran Central Veterinary Laboratory, Tehran, Iran

${ }^{3}$ FMD Institute, Ankara, Turkey

${ }^{4}$ National Veterinary Institute, Technical University of Denmark, Lindholm, Denmark

${ }^{5}$ Current address: Department of Veterinary and Animal Sciences, Faculty of Health and Medical Sciences, University of Copenhagen, Frederiksberg C, Denmark

\section{* Corresponding author}

Email address: grbe@sund.ku.dk

This article has been accepted for publication and undergone full peer review but has not been through the copyediting, typesetting, pagination and proofreading process, which may lead to differences between this version and the Version of Record. Please cite this article as doi: 10.1111/TBED.13433

This article is protected by copyright. All rights reserved 


\section{Summary}

Phylogenetic studies on foot-and-mouth disease viruses (FMDVs) circulating in the West Eurasian region have largely focused on the genomic sequences encoding the structural proteins that determine the serotype. The present study has compared near complete genome sequences of FMDVs representative of the viruses that circulate in this region. The near complete genome sequences (ca. 7600nt) were generated from multiple overlapping RT-PCR products. These amplicons were from FMDVs belonging to serotypes O, A and Asia-1, including members of the O-PanAsia-II and the AIran05 lineages, and of Group-II and Group-VII (Sindh-08) within serotype Asia-1, which are currently predominant and widespread in West Eurasia. These new sequences were analysed together with other sequences obtained from GenBank. Comparison of different regions of the FMDVs genomes revealed evidence for multiple, inter-serotypic, recombination events between FMDVs belonging to the serotypes $\mathrm{O}, \mathrm{A}$ and Asia-1. It is concluded from the present study that dramatic changes in virus sequences can occur in the field through recombination between different FMDV genomes. These analyses provide information about the ancestry of the serotype $\mathrm{O}$, A and Asia-1 FMDVs that are currently circulating within the West Eurasian region.

\section{Key words:}

FMDV, mosaic genome, picornavirus, RNA 


\section{Introduction}

Foot-and-mouth disease virus (FMDV), the prototypic member of the genus Aphthovirus within the family Picornaviridae, is the causative agent of foot-and-mouth disease (FMD), an infectious and highly contagious disease of cloven-hoofed animals (Jamal and Belsham, 2013; Jamal and Belsham, 2018). FMDV particles consist of a single stranded positive-sense RNA, about $8.4 \mathrm{~kb}$ in length, surrounded by a protein shell or capsid (Acharya et al., 1989).

The FMDV genome contains a single, large, open reading frame (ORF) flanked by highly structured 5'- and 3'-untranslated regions (termed the 5'-UTR and 3'-UTR, respectively). The 5'-UTR is about $1300 \mathrm{nt}$ in length and comprises, from its 5'- terminus, a short (S) fragment, a poly $(\mathrm{C})$ tract, 3-4 tandemly repeated pseudoknots, a cis-acting replication element (cre) and the internal ribosomal entry site (IRES) (Martinez-Salas and Belsham, 2017). The 3'-UTR (about 90 nt long) is much shorter than the 5'-UTR; this heteropolymeric sequence is followed by a poly(A) tract of variable length (Agol et al. 1999).

The ORF, about $7000 \mathrm{nt}$ in length, is the major portion of the viral genome and encodes a large polyprotein which is processed, during and after synthesis, to generate 15 different mature proteins plus multiple precursors (Martinez-Salas and Belsham, 2017). Early processing products include the Leader proteinase ( $\mathrm{L}^{\text {pro }}$ ), the P1-2A capsid precursor plus $\mathrm{P} 2$ and $\mathrm{P} 3$. The $\mathrm{L}^{\text {pro }}$ is made in two different forms, $\mathrm{Lab}$ and $\mathrm{Lb}$, due to the use of two separate initiation codons that are usually 84 nt apart (see Belsham, 2013; Sanger et al., 1977). The P1-2A precursor is processed by the $3 \mathrm{C}$ protease (3Cpro) to VP0, VP3 and VP1 plus 2A. The P2 yields the non-structural proteins $2 \mathrm{~B}$ and 2C while the P3 precursor is processed to 3A, the 3 distinct copies of the genome linked viral protein (VPg, also termed $3 \mathrm{~B})$, the $3 \mathrm{C}$ protease $\left(3 \mathrm{C}^{\mathrm{pro}}\right)$ and the RNA dependent RNA polymerase (3D $\left.{ }^{\mathrm{pol}}\right)$.

There are seven distinct serotypes of FMDV, i.e. O, A, C, Asia 1, SAT 1, SAT 2 and SAT 3, that do not induce cross-protection against each other, after either infection or vaccination (Bachrach, 1968; Domingo et al., 2003). Within these serotypes, multiple lineages (or sub-lineages) can be identified that sometimes fail to induce efficient cross-protection against other viruses from within the same serotype (see Jamal and Belsham, 2013; Jamal et al., 2011a,b; Bachanek-Bankowska et al., 2019). In addition, the control of the disease is constantly challenged by the emergence of new strains (e.g. see

This article is protected by copyright. All rights reserved 
review by Jamal and Belsham, 2018). Serotypes O, A, C and Asia-1 FMDVs have been divided into genotypes, lineages and sub-lineages based on $<15 \%,<7.5 \%$ and $<5 \%$ differences in the VP1 coding sequences, respectively (Knowles and Samuel, 2003; Hemadri et al., 2002). Genetic heterogeneity within FMDVs may arise as a result of continuous genetic drift Dopazo et al., 1988), due to selection pressure (Haydon et al., 2001; Tully and Fares, 2008) or as a result of recombination between different FMDV genomes (Carrillo et al., 2005; Jamal et al., 2011b). The detection of recombination requires simultaneous infection of cells with two distinguishable strains of virus, which is clearly facilitated in the field by co-circulation of different serotypes/lineages of FMDV.

West Eurasia is considered to maintain an independent pool, termed Pool 3, of FMDVs including serotypes O, A and Asia 1, with only occasional incursions of FMDVs from other virus pools (Paton et al., 2009; Jamal and Belsham, 2013). Epidemics emerging within this region frequently involve multiple, neighbouring, countries. In recent years, the boundaries of the epidemics due to strains of O-PanAsia (Brito et al., 2017; Brito et al., 2013; Jamal et al., 2011c), A-Iran05 (Jamal et al., 2011a; Knowles et al., 2009) and Asia-1 (a new lineage designated as Group-VII (Sindh-08), Jamal et al., 2011b), have been seen to extend from Pakistan/Afghanistan/Iran through to Turkey. In addition, there have been occasional short incursions of these viruses into Central Asia and the Middle-East, including Israel. Epidemics due to serotype O-PanAsia strains and viruses of the A-Iran05 lineage have been recorded in North Africa while O-PanAsia-II ${ }^{\text {ANT-10 }}$ viruses have been found to be responsible for the outbreak in Bulgaria in 2011, a previously disease-free European country (Valdazo-Gonzalez et al., 2012; Brito et al., 2013).

Previous phylogenetic studies on FMDVs circulating in the West Eurasian region have largely focused on genome regions encoding the structural proteins which determine the virus serotype (Brito et al., 2013; Jamal et al., 2011a,b,c; Knowles et al., 2009; Waheed et al., 2011). In contrast, the present study has compared near complete genome sequences of FMDVs representative of the three serotypes that each circulate in this region and this analysis has provided evidence for multiple interserotypic recombination events.

\section{Materials and Methods:}

This article is protected by copyright. All rights reserved 


\section{Samples}

Oral swab and epithelial samples were collected from apparently healthy animals and also from suspected clinical cases of FMD in Pakistan and Afghanistan under an Italian-funded FAO Regional Project (GTFS/INT/907/ITA), as described previously (Jamal et al., 2011a, b,c; Jamal et al., 2012). In addition, samples from suspected cases of FMD were collected in Iran and Turkey. Samples from Pakistan, Afghanistan and Iran were transported to the National Veterinary Institute, Technical University of Denmark (DTU Vet), Lindholm, Denmark, whereas, samples from Turkey were analysed at the Foot-and-mouth disease Institute, Ankara, Turkey. A list of samples and sequences analysed for this study is presented in Table 1.

\section{RNA extraction, $R T-P C R$ and sequencing}

- Sample preparation, RNA extraction from the oral swabs and epithelial samples and RT-PCR were carried out as described previously (Jamal et al., 2011a,b,c). The nucleotide sequences encoding all the capsid proteins (within P1) together with the Leader protease (L ${ }^{\text {pro }}$ ) were obtained by generating 4 separate overlapping amplicons by RT-PCR, which were then sequenced in both directions using primers described in Jamal et al. (2011a). Sequencing reactions were performed using Big DyeTerminator v3.1 Cycle Sequencing Reaction Kit on an ABI 3730 DNA Analyzer (Applied Biosystems) following the manufacturer's instructions. Sequences were assembled, proof-read and edited using SeqMan Pro (DNASTAR). Near complete genome sequences (ca. 7600nt) (that include the complete coding sequence) were generated from representative samples by generating 15 separate overlapping RT-PCR products using primers described previously (Jamal et al., 2011b). The sequences determined in this study have been submitted to the EMBL/GenBank/DDBJ databases; accession numbers are listed in Table 1. Nucleotide sequence data, encoding the 4 capsid proteins (within P1) and complete genome sequences of FMDVs circulating in the West Eurasian region and other representative viruses, were obtained from public databases (www.ncbi.nlm.nih.gov) and included in the analyses.

\section{Phylogenetic analyses}

This article is protected by copyright. All rights reserved 
The sequences were aligned and selected regions of the genome, as indicated, were analysed separately. Phylogenetic trees were constructed from each region using the Maximum Likelihood method based on the Tamura-Nei model (Tamura and Nei, 1993) within MEGA version 7 as described (Kumar et al., 2016). A discrete Gamma distribution was used to model evolutionary rate differences among sites. The tree was drawn with branch lengths in proportion to the number of substitutions per site. The robustness of the tree topology for each dataset was assessed with 1000 bootstrap replicates (Felsenstein, 1985) and a bootstrap value of $\geq 70 \%$ was considered significant.

\section{Recombination analysis}

In order to assess the possibility of recombination events between different viruses, multiple regions of the FMDV genome sequences (e.g. encoding individual proteins or their precursors) from different serotypes were compared using BLAST. Further analyses for recombination were performed using SimPlot 3.5.1 software (Lole et al., 1999). Briefly, the near complete genome nucleotide sequences, either generated in this study or determined previously and submitted to databases, were aligned using ClustalW implemented in MEGA version 6. Pair-wise genetic similarities were plotted between the query sequences and a set of reference sequences using a window size of 200 nucleotides moving in steps of 20 nucleotides along the alignment. The pair-wise identity values were plotted at the midpoint of each window.

\section{Results}

The nucleotide sequences encoding all the capsid proteins of two viruses plus 10 near complete genome sequences from different FMDVs belonging to serotypes $\mathrm{O}$ and $\mathrm{A}$ that have been circulating recently in Pakistan, Afghanistan, Iran and Turkey were generated in this study (accession numbers of the sequences generated in this study are listed in Table 1). These sequences were analysed together with other FMDV sequences obtained from GenBank. In total, 86 nucleotide sequences were compared and analysed (Table 1). The selected regions of the genome analysed included part of the 5'-UTR (ca. $500 \mathrm{nt}$ ) and the complete coding sequences for $\mathrm{L}^{\text {pro }}$, all the capsid proteins together (i.e. P1), P2, 3A and the rest of P3 (3BCD), plus the near complete genome sequences of FMDV. This 
collection of FMDV sequences contained representative viruses of serotypes $\mathrm{O}$, A and Asia-1 including the O-PanAsia strains, members of the A-Iran05 lineage plus viruses belonging to Group-II and Group-VII (Sindh-08) within the Asia-1 serotype. These viruses are currently predominant and widespread in West Eurasia.

From these sequence comparisons, an insertion of a single nucleotide (T) was found in a rescued virus $(\mathrm{O} / \mathrm{KAB} / \mathrm{AFG} / \mathrm{LI}-709 / 2009)$ at position 64 of the Lab ${ }^{\text {pro }}$ coding region, which is between the two functional initiation codons. The insertion of this single nucleotide results in a shift in the reading frame for products initiated at the Lab start site, however, translation products initiated from the frequently used Lb start site are not expected to be affected by this change. The original virus sample (O/KAB/AFG/L2826/2009), whose RNA was used for virus rescue (Belsham et al., 2011) did not have this insertion.

\section{Phylogenetic analyses}

Phylogenetic analyses were performed for separate parts of the near full-length FMDV genome sequences derived from the three serotypes of the virus that are circulating within West Eurasia.

\section{a) Capsid protein coding sequences}

Viruses belonging to serotype Asia-1 have a capsid protein (P1) coding region of 2193 nucleotides except for one virus (PAK/1/54) in which a deletion of one codon, at position 1717-1719 (encoding residue 47 in VP1), was observed. This region of the serotype $\mathrm{O}$ viruses has a length of 2202 nucleotides. Serotype A FMDVs have a P1 coding region of 2205 nucleotides except for one serotype A virus (A/SAU/1/2015; accession No. KU127247) which has a deletion of one codon at position 1087-1089. Alignment of nucleotides in the P1 coding region for the serotype Asia-1 viruses showed the deletion of three nucleotides at positions 1087-1089 (resulting in loss of residue 57 from VP3 (D/E) and six nucleotides at positions 1993-1998 (removing residues 143 (N/R/T/G) and 144 (V) from VP1). Insertion of two codons, one at position 1309-1311 (encoding residue 131 (T/A) in VP3) and the second at position 2164-2166 (encoding residue 196 (V) in VP1) were observed in all of the serotype A FMDVs studied here. One FMDV (A/PAK/3/2006), belonging to the A-Iran05 lineage, differed from the rest of the FMDVs belonging to this serotype. It has an insertion of six nucleotides at position 724-729 (encoding residues P157 and H158 in VP2) and deletion of two codons, at

This article is protected by copyright. All rights reserved 
positions 157-159 (encoding a normally invariant residue D53 in VP4) and 760-762 (encoding another usually invariant residue R169 in VP2), respectively.

The serotypes of FMDVs are sub-divided into genotypes, lineages and sub-lineages based on differences in the VP1 coding sequences, thus phylogenetic analyses were performed using these sequences (Figure 1a). Phylogenetic trees based on the VP1 coding region clustered all the FMDVs studied here into groups following a serotype-specific branching pattern, as expected. The viruses were further divided into different lineages and sub-lineages within the individual serotypes. The same branching pattern was also observed when phylogenetic trees were constructed using the VP2 and VP3 coding sequences (data not shown). However, the branching pattern in the phylogenetic tree obtained using the less variable VP4 coding sequences was different (Figure 1b). Notably, the VP4 sequences of viruses belonging to the Group-VII (Sindh-08) of serotype Asia-1 (As/SIN/PAK/L5/2008 and As/TUR/13/2013) diverged from the rest of the serotype Asia-1 FMDVs and clustered with O-PanAsia viruses. However, the VP4 coding region of As/SIN/PAK/L2812/2009, another member of Group-VII (Sindh-08) of serotype Asia-1 FMDV, showed closest identity to viruses belonging to the A-Iran05 lineage; this virus has been reported as being recombinant previously (Jamal et al., 2011b). The branching pattern within the phylogenetic tree constructed using the entire structural protein coding region (P1) was, however, the same as for the coding sequences of VP1 alone (Figure 2a).

\section{b) Partial 5'-UTR sequences}

About 510 nucleotides of the 5'-UTR from the region adjacent to the coding sequence (including the entire IRES) were aligned and compared (Figure 2b). The clustering of these sequences did not follow the serotype-specific grouping pattern observed, in Figure 1a, for the capsid protein coding sequences. The 5'-UTRs from the serotype O-PanAsia viruses studied here were mainly found to be present in two separate groups, one formed by the O-PanAsia-I viruses and the other by the O-PanAsia-II. Viruses belonging to the O-PanAsia-II ${ }^{\mathrm{ANT}-10}$ strain formed one cluster that was distinct from the rest of the O-PanAsia-II viruses. For this region, many of the viruses belonging to the O-PanAsia-II ${ }^{\mathrm{PUN}-05}$, O-PanAsia-II ${ }^{\text {PUN-10 }}$, O-PanAsia-II ${ }^{\text {FAR-09, O-PanAsia-II }}{ }^{\text {BAL-09 }}$ and O-PanAsia-II ${ }^{\text {TER-08 }}$ sub-lineages clustered together and formed a distinct group. However, the 5'-UTRs of some of the viruses 
belonging to the O-PanAsia-II ${ }^{\mathrm{PUN}-05}$ sub-lineage did not fit into a single group, hence this sub-lineage could be divided into two separate sub-groups. Almost all of the 5'-UTR sequences, within the viruses belonging to the A-Iran05 lineage, clustered together except for two viruses, A/TUR/11/2013 and A/SIN/PAK/L4/2008, which showed closest identity to the O-PanAsia-IIPUN-05 viruses and As/SIN/PAK/L2810/2009, respectively. The 5'-UTR of A22/Iraq/64 sequence did not cluster with the A-Iran05 viruses (see Figure 2b), rather it showed closer identity with O/Nari/UVAS-Pak/2005, a virus belonging to the serotype O Pak-98 lineage (see Figure 1a). The A/TUR/004/2003 (accession No. JF749848) 5'-UTR sequence also did not cluster with the A-Iran05 viruses but showed closer identity with As/Ind/82-96 virus. The 5'-UTR sequences of the serotype Asia-1 viruses did not form a single group either; thus, as for the other virus serotypes, these were distributed among the different serotype $\mathrm{O}$ and A FMDVs studied here. Thus, the 5'-UTR behaves as an independent unit that is separable from its adjacent coding sequences.

\section{c) Leader protease (Lro) coding sequences}

FMDVs belonging to serotypes O, A and Asia-1 each had an Lpro coding region of 603 nt except for eight out of 11 serotype A-Iran05 viruses in which it was found to be $609 \mathrm{nt}$ in length due to insertion of $6 \mathrm{nt}$ at position 85-90. Insertion of these additional nucleotides in this lineage has been reported previously (Klein et al., 2007).

Unlike the serotype-specific branching pattern of the VP1 coding sequences alone and the capsid coding sequences (Figure 1a and 2a), the L pro coding sequences did not follow serotype-specific clustering (Figure 2c). This clustering pattern was also different from that of the 5'-UTR (see Figure $2 b$ ). The serotype $\mathrm{O}$ viruses, that were analysed here, formed two distinct groups. Viruses belonging to the O-PanAsia-I and O-PanAsia-II ${ }^{\mathrm{ANT}-10}$ sub-lineages clustered together to form one group, whereas viruses belonging to the rest of the O-PanAsia-II lineage clustered to form a second group. Serotype Asia-1 viruses also showed divergence within this region of the genome. As is evident from Figure 2c, the L $L^{\text {pro }}$ coding sequences from As/SIN/PAK/L5/2008 (accession No. JN006719) and As/TUR/134/2013 (accession No. KM268898), both belonging to Group-VII (Sindh-08) of serotype Asia-1, showed closest identity to viruses belonging to the O-PanAsia-II ${ }^{\mathrm{ANT}-10}$ sub-lineage while the $L^{\text {pro }}$ sequence from As/SIN/PAK/2810/2009 (accession No. JN006720) (another member of Group- 
VII) showed highest similarity to A/SIN/PAK/L4/2008 (accession No. JN0006722). The As/SIN/PAK/2810/2009 sequence has previously been reported to be derived from a recombinant virus (Jamal et al., 2011b), the coding regions for VP2, VP3 and VP1 show close identity to As/SIN/PAK/L5/2008 (accession No. JN006719), whereas, the remaining portions of its genome show closest identity to A/SIN/PAK/L4/2008. Similarly, the $\mathrm{L}^{\text {pro }}$ sequences from viruses belonging to Group-II of serotype Asia-1 clustered with the O-PanAsia-I viruses. The $\mathrm{L}^{\text {pro }}$ coding sequences from viruses belonging to serotype A FMDVs also did not form a single group except for the A-Iran05 lineage. These mainly formed a separate cluster, except for 3 viruses (A/SIN/PAK/L4/2008, $\mathrm{A} / \mathrm{PAK} / 76 / 2009$ and $\mathrm{A} / \mathrm{TUR} / 11 / 2013)$ that showed divergence from this group and clustered predominantly with the O-PanAsia-II viruses. Surprisingly, the L ${ }^{\text {pro }}$ sequence from A22/IRQ/24/64 and A/TUR/004/2003 showed closer similarity to As/PAK/1/54 than to the other serotype A viruses (Figure 2c).

\section{d) P2 coding region}

All the viruses analysed here have a P2 coding region of 1416 nucleotides. The P2 coding sequences did not cluster into a serotype-specific pattern either, in fact their grouping pattern (Figure 2d) was almost the same as for the $\mathrm{L}^{\text {pro }}$ coding sequences (Figure 2c). However, two viruses, belonging to the A-Iran05 lineage (i.e. A/TUR/11/2013 and A/SIN/PAK/4/2008) that had diverged from other viruses in this lineage within the $\mathrm{L}^{\text {pro }}$ coding sequences, converged into one group for the $\mathrm{P} 2$ sequences. In contrast, another virus (A/BAD/AFG/L2813/2009) was separate from this group and showed closer identity to the $\mathrm{P} 2$ region of As/PAK/1/54 than to other serotype A viruses. Furthermore, the P2 region of As/BAM/AFG/L590/2009 (accession No. HQ113233) diverged from other Asia-1 viruses in GroupII and clustered with viruses belonging to the O-PanAsia-II lineage. As with the $\mathrm{L}^{\text {pro }}$ coding sequences, two viruses belonging to the Group-VII (Sindh-08) of serotype Asia-1 (i.e. As/SIN/PAK/L5/2008 and As/TUR/13/2013), showed closest identity with the O-PanAsia-II ${ }^{\text {ANT-10 }}$ viruses in the P2 coding region.

e) P3 coding region

This article is protected by copyright. All rights reserved 
All the viruses analysed had P3 coding sequences of $2724 \mathrm{nt}$ except for one serotype Asia-1 virus (As/PAK/30/2002, accession No. JF749849), in which deletion of three nucleotides at nt position 523525 has occurred, and one serotype A virus (A/PAK/3/2006) that had an insertion of three nucleotides at nt position 1228-1230.

The P3 coding sequences also did not follow the serotype-specific branching pattern. Furthermore, the grouping of the serotype $\mathrm{O}$ viruses for this part of the genome was also different from that observed for the $\mathrm{L}^{\text {pro }}$ and $\mathrm{P} 2$ coding regions. Phylogenetic trees constructed using the whole P3 coding sequences or the $3 \mathrm{BCD}$ regions alone had very similar branching patterns (not shown). However, differences were apparent when phylogenetic trees were constructed using the 3BCD and 3A regions separately. The O-PanAsia-II ${ }^{\mathrm{ANT}-10}$ viruses diverged into two sub-groups in the $3 \mathrm{BCD}$ coding sequences unlike their grouping pattern in the 5'-UTR and the L pro, P1-2A, and P2 coding sequences (compare Figure 2f, 2a, 2b, 2c and 2d). Serotype A viruses did not form a single cluster for the 3BCD coding sequences either, although the parental A-Iran05 viruses grouped together. The A/TUR/11/2013, belonging to the A-Iran05 ${ }^{\text {IIS-10 }}$ sub-lineage, showed closer identity in the $3 \mathrm{BCD}$ region with viruses belonging to the O-PanAsia-II ${ }^{\mathrm{ANT}-10}$ sub-lineage than to the other A-Iran05 viruses. Similarly, A/BAD/AFG/L2813/2009 (in the A-Iran05 ${ }^{\text {BAD-09 }}$ sub-lineage), A/SIN/PAK/L4/2008 (in the A-Iran05 ${ }^{\mathrm{AFG}-07}$ sub-lineage) and A/SIN/PAK/L639/2009 (in the A-Iran05 ${ }^{\text {BAR-08 }}$ sub-lineage) clustered with the O-PanAsia-II viruses for this region (Figure 2e). The 3BCD sequence of A/SAU/1/2015, a pool 2 virus, showed close identity with serotype Asia-1 viruses from the same virus pool. Serotype Asia-1 viruses did not form a discrete group but were found dispersed among all the viruses in this tree (Figure 2f).

Some differences were also noted in the grouping pattern of particular viruses based on the $3 \mathrm{BCD}$ coding region compared to the $3 \mathrm{~A}$ coding region. For example, the grouping pattern of As/SIN/PAK/L5/2008 and As/SIN/PAK/L2810/2009, both belonging to the Group-VII (Sind-08) within serotype Asia-1, were different for the 3BCD coding region compared to that obtained for the 3A coding region (compare Figure 2e and Figure 2f). Furthermore, the As/SIN/PAK/L5/2008, while showing closest identity with the O-PanAsia-II ${ }^{\mathrm{ANT}-10}$ viruses in the $3 \mathrm{BCD}$ coding region, showed closer identity with viruses belonging to the O-PanAsia-I lineage within 3A. Viruses belonging to the 
O-PanAsia-II ${ }^{\mathrm{PUN}-05}$ sub-lineage formed two sub-groups in the 3A tree (one sub-group consisting of O/ISL/PAK/L1573, O/PUN/PAK/L1358/2008 and O/ISL/PAK/L1412/2009 showed closest identity with parental A-Iran05 viruses), while these viruses all formed just one group in the $3 \mathrm{BCD}$ tree.

\section{Recombination analysis}

As indicated above, the phylogenetic comparisons for different regions of the FMDV genomes showed different grouping patterns and clearly showed that for some viruses (e.g. O/BUL/1/2010 (accession No. JX040485), A/TUR/11/2013 (accession No. KM268896), As/BAM/AFG/L590/2009 (accession No. HQ113233) and As/PAK/30/2002 (accession No. JF749849)), particular regions of the genome were most closely related to sequences from other serotypes (see Figures 1 and 2). These results suggested inter-serotypic recombination between viruses had produced chimeric genomes. In order to analyse this further, defined regions of the genome of the FMDV serotypes O, A and Asia-1 circulating in West Eurasia were aligned and compared. The level of nt identity for the different regions of the FMDV genomes between the putative recombinant viruses and other selected viruses were calculated (see Supplementary Tables 1-5). In addition, recombination analyses were performed by plotting pair-wise genetic identity values between the putative recombinant viruses and other selected viruses circulating in West Eurasia using SimPlot.

It is evident from Supplementary Table 1 and the SimPlot analysis (Figure $3 \mathrm{~A}$ ), that the $\mathrm{L}^{\text {pro }}$ and P3 coding regions of $\mathrm{O} / \mathrm{BUL} / 1 / 2010$ show the closest similarity to viruses belonging to the Group-VII (Sindh-08) strain of serotype Asia-1 FMDVs (e.g. As/SIN/PAK/L5/2008). The partial 5'- UTR of this serotype $\mathrm{O}$ virus, however, has the highest nt sequence identity to viruses belonging to the A-Iran05 lineage (apart from other putative recombinants), whereas, the VP4, VP2, VP3 and VP1 coding sequences each show closest identities with that of other serotype $\mathrm{O}$ viruses, which is consistent with the serotype designation.

Similarly, the A/TUR/11/2013 sequence shows a high level of identity in the partial 5'-UTR and Lro coding region to serotype O FMDVs belonging to the O-PanAsia-II ${ }^{\mathrm{PUN}-05}$ sub-lineage (e.g.

O/PAK/45/2008) (see Supplementary Table 2 and Figure 3B). However, the P3 coding sequences and 3 '-UTR of this virus have the closest identity to viruses belonging to the O-PanAsia-II ${ }^{\mathrm{ANT}-10}$ sublineage (as shown for $\mathrm{O} / \mathrm{KHO} / \mathrm{IRN} / \mathrm{L} 1 / 2010$ ). The capsid coding region of this virus, however, shows

This article is protected by copyright. All rights reserved 
closest identity with viruses belonging to the A-Iran05 lineage (Supplementary Table 2 and Figure 3B), as expected.

As seen in Supplementary Table 3 and the SimPlot in Figure 4A, the $\mathrm{L}^{\text {pro }}$ and capsid coding region of the Asia-1/BAM/AFG/L590/2009 virus shows closest identity to As/HNK/CHA/1/2005 (accession number EF149010), which belongs to the Group-II of Asia-1 FMDVs. However, the P3 coding region and 3'- UTR of this virus show closest identity to the O-PanAsia-II viruses (particularly to the parental O-PanAsia-II virus, O/NWF/PAK/L1370/2009 and those belonging to the O-PanAsia-IIPUN-10 (e.g. O/NWF/PAK/L1417/2009 and O-PanAsia-II TER-08 (e.g. O/Israel/2007; accession No. FJ175666) sub-lineages. These data clearly indicate a chimeric nature for this genome consistent with recombination.

The Lro, P2, P3 coding sequences and the 3'-UTR of Asia-1/PAK/30/2002 (within the Group-II of serotype Asia-1 FMDV) show the closest identity to O/IRN/73/2001 and O/UKG/35/2001, both within the O-PanAsia-1 lineage. In contrast, the capsid coding region of this virus shows closest identity to viruses belonging to the Group-II of serotype Asia-1 FMDV (e.g. Asia/HNK/CHA/05 (accession No. EF149010) and As/BAM/AFG/L590/2009) (see Supplementary Table 4 and Figure 4B). Thus, this virus also appears to have a recombinant genome.

Finally, as is evident from Supplementary Table 5, the L ${ }^{\text {pro }}$ coding sequence of As/SIN/PAK/L5/2008 (belonging to the Group-VII (Sindh-08) of serotype Asia-1 FMDV) shows closest identity to the OPanAsia-1 viruses. Moreover, the VP4 coding sequences of this virus shows closer identity to serotype $\mathrm{O}$ viruses than serotype Asia-1 viruses, showing that this virus is also recombinant. The recombination event appears to have taken place somewhere around nt 150 from the 5' end of the VP2 coding sequences (data not shown). The 3A coding region of As/SIN/PAK/L5/2008 shows close identity with the O-PanAsia-1 viruses, whereas, its 3BCD coding sequences (like its P2 coding region, see above) shows closest identity with viruses belonging to the O-PanAsia-II ${ }^{\mathrm{ANT}-10}$ sub-lineage.

\section{Discussion}

Analysis of full genome sequences of FMDVs has significantly improved understanding of the virus biology (e.g. see Carrillo et al., 2005). It has allowed analysis of variability and sequence conservation between FMDV strains. In addition, full genome sequences of FMDVs have been used for identifying

This article is protected by copyright. All rights reserved 
the initial and intermediate sources of viruses responsible for the 2007 FMD outbreak in England (Cottam et al., 2008) and for tracing the virus spread during the outbreak in Bulgaria in 2011 (Valdazo-Gonzalez et al., 2012), which was not possible using partial genome sequence data. Furthermore, phylogenetic studies of FMDVs using full genome sequence data have revealed much more complex epidemiological relationships between different FMDV isolates than is apparent from analysis of short regions (e.g. encoding VP1 alone). Near full-length genome sequences of serotype O, A and Asia-1 FMDVs circulating in West Eurasia were generated in the present study and different regions of the genome were analysed and compared with other sequences available from public databases. The branching patterns of different parts of FMDV genome were different from each other. A serotype-specific branching pattern was only observed for the sequences coding for the whole structural protein precursor (P1-2A) and for the VP1 alone. Differences in branching patterns for different regions of the FMDV genomes revealed evidence for multiple, inter-serotypic, recombination events within FMDVs belonging to serotypes O, A and Asia-1.

It is well established that recombination between the RNA genomes of picornaviruses occurs. It has been observed within cells infected with two different strains of virus (e.g. McCahon et al., 1977; Agol et al., 1985). It has been demonstrated to occur by a "copy-choice" mechanism; basically, during the process of RNA replication, the RNA-dependent RNA polymerase switches from one positivesense template to another (Kirkegaard and Baltimore, 1986). Recombination can occur between very closely related viral RNAs (when it can be difficult to detect unless specific markers are included) but also between viruses of different serotypes. The detection of recombination requires that cells are simultaneously infected with two distinguishable strains of virus. Clearly, for the recombinant genomes to be maintained then they have to be infectious. This, undoubtedly, imposes constraints on the identification of locations at which such recombination events occur within the genome. Recombination is normally observed at low frequency within the capsid protein-coding region; one explanation for this is that chimeric capsids may frequently not be functional. It is clear that recombination between picornaviruses does occur in the field (Oberste et al., 2004; Heath et al., 2006; Simmonds et al., 2006; Huang et al., 2009; McIntyre et al., 2010; Chieochansin et al., 2011; Ferretti et al., 2018). 
Replication of the FMDV RNA genome is highly error-prone due to the absence of proof-reading activity of the viral RNA polymerase. Accumulation of genetic heterogeneity in FMDVs results from the selection of variants as a result of various different pressures (Tully and Fares, 2008; LewisRogers et al., 2008; Cookes and Westover, 2008; Balinda et al., 2010; Sangula et al., 2010; Yoon et al., 2011; Jamal et al., 2011c). Nucleotide substitutions within the VP1 coding region, at rates ranging from $1.4 \times 10^{-3}$ to $7.8 \times 10^{-3}$ substitutions/nt/yr, have been described for a range of different FMDVs (Villaverde et al., 1991; Martinez et al., 1992; Hemadri et al., 2002; Bastos et al., 2003; Tully et al., 2008; Balinda et al., 2010; Sangula et al., 2010; Jamal et al., 2011c; Yoon et al., 2011). This evolutionary rate (ca. $0.5-1 \%$ of the genome per year) suggests that new sub-lineages (with $>5 \%$ sequence difference) within these viruses can arise within a 5-10 year period. However, the higher evolutionary rate of about $1.2 \times 10^{-2}$ substitutions/nt/yr, calculated for the A-Iran05 lineage, suggests that new sub-lineages will evolve within a period of about three years (Jamal et al. 2011a). This is indeed consistent with the existence of multiple sub-lineages for the A-Iran05 lineage (Jamal and Belsham, 2018).

The present study reveals further examples of the dramatic changes in virus sequence that occur as a result of recombination between different FMDV genomes. The generation of recombinant FMDVs during passage in cell culture and mice, and in the field has been reported previously (Jackson et al., 2007). Such events have frequently been reported between different viruses of the same serotype. These have occurred within the coding region for the non-structural proteins (NSPs), within the 3' portion of the genome (Giraudo et al., 1987; Krebs and Marquardt, 1992; Li et al., 2007; Lee et al., 2009), in the $5^{\prime}$ end (Mohapatra et al., 2008), by exchange of the capsid coding region (BachanekBankowska et al., 2018) and even within the capsid coding region (Haydon et al., 2004;

Nagendrakumar et al., 2009). This usually occurs within highly conserved sequences (King, 1988) and, therefore, recombination that swaps VP4 sequences is expected to occur (and yield viable genomes) since the nucleotide sequences for this region of the genome are much more highly conserved among different FMDV serotypes than the rest of the capsid coding region. Viability constraints are most likely to operate within the VP2-VP3-VP1 coding region. There is some evidence 
for inter-serotypic recombination between FMDV strains in the field (Balinda et al., 2010; Jamal et al., 2011b). The current study provides additional evidence for recombination between different serotypes of FMDV, involving different regions of the FMDV genome encoding both the structural and nonstructural proteins, that has occurred between strains of the virus that are currently circulating in West Eurasia.

Earlier analyses of complete genome sequences of FMDVs belonging to the O-PanAsia-I lineage revealed a remarkable conservation with no intra- or inter-serotypic recombination (Mason et al., 2003). However, the present study identified viruses belonging to the O-PanAsia-II ${ }^{\mathrm{ANT}-10}$ sub-lineage as being recombinant with the $\mathrm{L}^{\text {pro }}, 3 \mathrm{~B}, 3 \mathrm{C}$ and $3 \mathrm{D}$ coding regions acquired from viruses belonging to the Group-VII (Sindh-08) of serotype Asia-1 FMDV and the 5'-UTR from viruses belonging to the

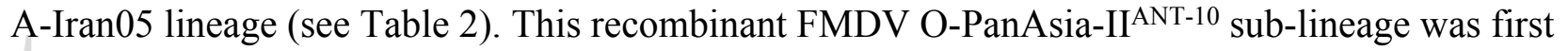
detected in Pakistan in early 2009 (Brito et al., 2013) and has spread widely throughout West Eurasia and continues to be responsible for major FMD outbreaks in the region. It has also crossed its usual geographic boundaries and has caused outbreaks in Libya in 2010 and in the previously disease-free European country, Bulgaria, in 2011 (see Valdazo-Gonzalez, 2012; Jamal and Belsham, 2018).

Recombination may play a role in the success of this sub-lineage in terms of its degree of infectiousness by combining different determinants of virulence. The commonly used vaccine strains in West Eurasia (O 3039, O Manisa and O Tur 5/09) are effective in containing spread of viruses belonging to the O-PanAsia-II ${ }^{\mathrm{ANT}-10}$ sub-lineage. However, the r1 values for two of the three viruses belonging to this sub-lineage (i.e. PAK/10/2016 and PAK/4/2017), that formed a distinct subgroup on the basis of the $3 \mathrm{~A}$ and $3 \mathrm{BCD}$ coding sequences, using antisera raised against these three vaccine strains, ranged between 0-0.1 (Bachanek-Bankowska et al., 2019) and thus do not match well.

Achieving recombination requires that an animal is co-infected with two different strains of FMDV simultaneously. Indeed, the same cells within the host need to be infected at the same time so that the viral RNA polymerase can switch between the two different FMDV RNA templates. When an animal is infected with FMDV, there is usually a fairly short, acute phase of infection (Paton et al., 2018). A 
high level of viremia is apparent for a few days and lesions, with high levels of virus, occur around the mouth and on the feet. After this phase, the infection subsides and the vesicles heal. However, many cattle (ca. 50\%) do not completely clear the infection and maintain a low level of infectious virus within the oropharynx for months or years. These animals are referred to as "carriers" (Salt, 1993; Sutmoller et al., 1968; Woodbury, 1995). It is not clear whether recombination between FMDVs occurs when the parental viruses both cause an acute infection in an animal simultaneously or if the infection of a "carrier" animal with a different virus is capable of allowing co-infection of cells with the two different strains of virus. The high level of virus present within an acutely infected animal may make it easier for individual cells within the host to be co-infected but, clearly, this imposes a fairly narrow time window for the co-infection of the animal to occur. On the other hand, re-infection of a "carrier" animal with a different strain of virus could occur after a time interval of weeks, months or even years. Appropriate experimental studies should permit differentiation between these alternative scenarios.

\section{Conflict of interests}

The authors declare that no conflict of interests exists

\section{Ethical statement}

The authors confirm that the ethical policies of the journal, as noted on the journal's author guidelines page, have been adhered to. No ethical approval was required as only standard diagnostic samples (mouth swabs and epithelium samples) were obtained from healthy animals and those with clinical signs of FMD. No experimentation on the animals was performed. 


\section{References}

Acharya, R., Fry, E., Stuart, D., Fox, G., Rowlands, D., \& Brown, F. (1989). The three-dimensional structure of foot-and-mouth disease virus at $2.9 \AA$ resolution. Nature, 337, 709-716.

Agol, V.I., Paul, A.V., \& Wimmer, E. (1999). Paradoxes of the replication of picornaviral genomes. Virus Res, 62, 129-147.

Agol, V.I., Drozdov, S.G., Grachev,V.P., Kolesnikova, M.S., Kozlov, V.G., Ralph, N.M., Romanova, L.I., Tolskaya, E.A., Tyufanov, A.V., \& Viktorova, E.G. (1985). Recombinants between attenuated and virulent strains of poliovirus type 1: derivation and characterization of recombinants with centrally located crossover points. Virology, 743, 467-477.

Bachanek-Bankowska, K., Wadsworth, J., Henry, E., Ludi, A.B., Bin-Tarif, A., Statham, B., King, D.P., Afzal, M., Hussain, M., Manzoor, S., Abubakar, M., \& Knowles, N.J. (2019). Genome sequence of antigenically distinct serotype $\mathrm{O}$ foot-and-mouth disease viruses from Pakistan. Microbiol Resour Announc, 8, e01397-18. doi: 10.1128/MRA.01397-18

Bachanek-Bankowska, K., Di Nardo, A., Wadsworth, J., Mioulet, V., Pezzoni, G., Grazioli, S., Brocchi, E., Kafle, S.C., Hettiarachchi, R., Kumarawadu, P.L., Eldaghayes, I.M., Dayhum, A.S., Meenowa, D., Sghaier, S., Madani, H., Abouchoaib, N., Hoang, B.H., Vu, P.P., Dukpa, K., Gurung, R.B., Tenzin, S., Wernery, U., Panthumart, A., Seeyo, K.B., Linchongsubongkoch, W., Relmy, A., Bakkali-Kassimi, L., Scherbakov, A., King, D.P., \& Knowles, N.J. (2018).

Sci Rep 8:14693. doi: 10.1038/s41598-018-32693-8.

Bachanek-Bankowska, K., Wadsworth, J., Thapa, B., King, D.P., \& Knowles, N.J. (2016). Complete Genome Sequence of a Serotype A Foot-and-Mouth Disease Virus from an Outbreak in Saudi Arabia during 2015. Genome Announc 4 (1), e01591-15.

Bachrach, H.L. (1968). Foot-and-mouth disease. Ann Rev Microbiol 22, 201-244.

Balinda, S.N., Siegismund, H.R., Muwanika, V.B., Sangula, A.K., Masembe, C., Ayebazibwe, C., Normann, P., \& Belsham, G.J. (2010). Phylogenetic analyses of the polyprotein coding sequences 
of serotype $\mathrm{O}$ foot-and-mouth disease viruses in East Africa: evidence for interserotypic recombination. Virol J, 7, 199. doi: 10.1186/1743-422X-7-199

Bastos, A.D., Haydon, D.T., Sangaré, O., Boshoff, C.I., Edrich, J.L., \& Thomson, G.R. (2003). The implications of virus diversity within the SAT 2 serotype for control of foot-and-mouth disease in sub-Saharan Africa. J Gen Virol, 84, 1595-1606.

Belsham, G.J. (2013). Influence of the Leader protein coding region of foot-and-mouth disease virus on virus replication. J Gen Virol, 94, 1486-1495.

Belsham, G.J., Jamal, S.M., Tjørnehøj, K., \& Bøtner, A. (2011). Rescue of foot-and-mouth disease viruses that are pathogenic for cattle from preserved viral RNA samples. PLoS One, 6, e14621. doi:10.1371/journal.pone.0014621

Brito, B., Rodriguez, L., Hammond, J., Pinto, J., \& Perez, A. (2017) Review of the global distribution of foot-and-mouth disease virus from 2007 to 2014. Transbound Emerg Dis, 64, 316-332.

Brito, B.P., Perez, A.M., Jamal, S.M., Belsham, G.J., Pauszek, S.J., Ahmed, Z., \& Rodriguez, L. (2013). Foot-and-mouth disease virus serotype O phylodynamics: genetic variability associated to epidemiological factors in Pakistan. Trans Emerg Dis, 60, 516-524.

Carrillo, C., Tulman, E., Delhon, G., Lu, Z., Carreno, A., Vagnozzi, A., Kutish, G., \& Rock, D. (2005). Comparative genomics of foot-and-mouth disease virus. J Virol, 79, 6487-6504.

Chieochansin, T., Vichiwattana, P., Korkong, S., Theamboonlers, A., \& Poovorawan, Y. (2011). Molecular epidemiology, genome characterization, and recombination event of human parechovirus. Virology, 421, 159-166. doi:10.1016/ j.virol.2011.09.021.

Cooke, J.N., \& Westover, K.M. (2008). Serotype-specific differences in antigenic regions of foot-andmouth disease virus (FMDV): a comprehensive statistical analysis. Infect Genet Evol, 8, 855-63.

Cottam, E.M., Wadsworth, J., Shaw, A.E., Rowlands, R.J., Goatley, L., Maan, S., Maan, N.S., Mertens, P.P., Ebert, K., Li, Y., Ryan, E.D., Juleff, N., Ferris, N.P., Wilesmith, J.W., Haydon, D.T., 
King, D.P., Paton, D.J., \& Knowles, N.J. (2008). Transmission pathways of foot-and-mouth disease virus in the United Kingdom in 2007. PLoS Pathog, 4:e1000050. doi: 10.1371/journal.ppat.1000050

Domingo, E., Escarmís, C., Baranowski, E., Ruiz-Jarabo, C.M., Carrillo, E., Núñez, J.I., \& Sobrino, F. (2003). Evolution of foot-and-mouth disease virus. Virus Res, 91, 47-63.

Dopazo, J., Sobrino, F., Palma, E.L., Domingo, E., \& Moya, A. (1988). Gene encoding capsid protein VP1 of foot-and-mouth disease virus: a quasispecies model of molecular evolution. Proc Natl Acad Sci USA, 85, 6811-6815.

Felsenstein, J. (1985). Confidence limits on phylogenies: an approach using the bootstrap. Evolution, 783-791.

Ferretti, L., Di Nardo, A., Singer, B., Lasecka-Dykes, L., Logan, G., Wright, C.F., Pérez-Martín, E., King, D.P., Tuthill, T.J., \& Ribeca, P. (2018) Within-host recombination in the foot-and-mouth disease virus genome. Viruses, 10, E221. doi: 10.3390/v10050221.

Giraudo, A.T., Sagedahl, A., Bergmann, I.E., La Torre, J.L., \& Scodeller, E.A. (1987). Isolation and characterization of recombinants between attenuated and virulent aphthovirus strains. J Virol, 61, 419-425.

Haydon, D.T., Bastos, A.D., \& Awadalla, P. (2004). Low linkage disequilibrium indicative of recombination in foot-and-mouth disease virus gene sequence alignments. J Gen Virol, 85, 10951100.

Haydon, D.T., Bastos, A.D., Knowles, N.J., \& Samuel, A.R. (2001). Evidence for positive selection in foot-and-mouth disease virus capsid genes from field isolates. Genetics, 157, 7-15.

Heath, L., Van Der Walt, E., Varsani, A., \& Martin, D.P. (2006). Recombination patterns in Aphthoviruses mirror those found in other Picornaviruses. J Virol, 80, 11827-11832. doi:10.1128/JVI.01100-06.

This article is protected by copyright. All rights reserved 
Hemadri, D., Tosh, C., Sanyal, A., \& Venkataramanan, R. (2002). Emergence of a new strain of type $\mathrm{O}$ foot-and-mouth disease virus: its phylogenetic and evolutionary relationship with the PanAsia pandemic strain. Virus Genes, 25, 23-34.

Huang, T., Wang, W., Bessaud, M., Ren, P., Sheng, J., Yan, H., Zhang, J., Lin, X., Wang, Y., Delpeyroux, F., \& Deubel, V. (2009). Evidence of recombination and genetic diversity in human Rhinoviruses in children with acute respiratory infection. PLoS One, 4 (7),e6355. doi: 10.1371/journal.pone.0006355.

Jamal, S.M., \& Belsham, G.J. (2013). Foot-and-mouth disease: past, present and future. Vet Res, 44, 116. doi: 10.1186/1297-9716-44-116.

Jamal, S.M., \& Belsham, G.J. (2018). Molecular epidemiology, evolution and phylogeny of foot-andmouth disease virus. Infect Genet Evol, 59, 84-98. doi: 10.1016/j.meegid.2018.01.020.

Jamal, S.M., Ferrari, G., Ahmed, S., Normann, P., Curry, S., \& Belsham, G.J. (2011a). Evolutionary analysis of serotype A foot-and-mouth disease viruses circulating in Pakistan and Afghanistan during 2002-2009. J Gen Virol, 92, 2849-2864.

Jamal, S.M., Ferrari, G., Ahmed, S., Normann, P., \& Belsham, G.J. (2011b), Molecular characterization of serotype Asia-1 foot-and-mouth disease viruses in Pakistan and Afghanistan; emergence of a new genetic Group and evidence for a novel recombinant virus. Infect Genet Evol, 11, 2049-2062.

Jamal, S.M., Ferrari, G., Ahmed, S., Normann, P., \& Belsham, G.J. (2011c). Genetic diversity of footand-mouth disease serotype O viruses from Pakistan and Afghanistan, 1997-2009. Infect Genet Evol, $11,1229-1238$.

Jamal, S.M., Ferrari, G., Hussain, M., Nawroz, A.H., Aslami, A.A., Khan, E., Murvatulloev, S., Ahmed, S., \& Belsham, G.J. (2012). Detection and genetic characterization of foot-and-mouth disease viruses in samples from clinically healthy animals in endemic settings. Transbound Emerg Dis, 59, $429-440$.

This article is protected by copyright. All rights reserved 
Kanno,T., Yamakawa,M., Yoshida,K., \& Sakamoto,,K. (2002). The complete nucleotide sequence of the PanAsia strain of foot-and-mouth disease virus isolated in Japan. Virus Genes, 25, 119-125.

King, A.M.Q. (1988) Preferred sites of recombination in poliovirus RNA: an analysis of 40 intertypic cross-over sequences. Nucleic Acids Res, 16,11705-11723.

Kirkegaard, K., \& Baltimore, D. (1986). The mechanism of RNA recombination in poliovirus. Cell 47, 433-443.

Klein, J., Hussain, M., Ahmad, M., Normann, P., Afzal, M., \& Alexandersen, S. (2007). Genetic characterisation of the recent foot-and-mouth disease virus subtype A/IRN/2005. Virol J, 4, 122.

Knowles, N., Nazem Shirazi, M., Wadsworth, J., Swabey, K., Stirling, J., Statham, R., Li, Y., Hutchings, G., Ferris, N., \& Parlak, Ü. (2009). Recent spread of a new strain (A-Iran-05) of foot-andmouth disease virus type A in the Middle East. Transbound Emerg Dis, 56, 157-169.

Knowles, N.J., \& Samuel, A.R. (2003). Molecular epidemiology of foot-and-mouth disease virus. Virus Res 91, 65-80.

Krebs, O., \& Marquardt, O. (1992). Identification and characterization of foot-and-mouth disease virus O1 Burgwedel/1987 as an intertypic recombinant. J Gen Virol, 73:613-619.

Kumar, S., Stecher, G., \& Tamura, K. (2016). MEGA7: Molecular Evolutionary Genetics Analysis version 7.0 for bigger datasets. Mol Biol Evol, 33, 1870-1874.

Lee, K-N., Oem, J-K., Park, J-H., Kim, S-M., Lee, S-U., Tserendorj, S., Sodnomdarjaa, R,, Joo, Y-S., \& Kim, H. (2009). Evidence of recombination in a new isolate of foot-and-mouth disease virus serotype Asia 1. Virus Res, 139, 117-121.

Lewis-Rogers, N., McClellan, D.A., \& Crandall, K.A. (2008). The evolution of foot-and-mouth disease virus: impacts of recombination and selection. Infect Genet Evol 8, 786-798.

This article is protected by copyright. All rights reserved 
Li, D., Shang, Y.J., Liu, Z.X., Liu, X.T., \& Cai, X.P. (2007). Comparisons of the complete genomes of two Chinese isolates of a recent foot-and-mouth disease type Asial virus. Arch Virol, 152, 16991708.

Logan, G., Freimanis, G.L., King, D.J., Valdazo-Gonzalez, B., Bachanek-Bankowska, K., Sanderson, N.D., Knowles, N.J., King, D.P., \& Cottam, E.M. (2014). A universal protocol to generate consensus level genome sequences for foot-and-mouth disease virus and other positive-sense polyadenylated RNA viruses using the Illumina MiSeq. BMC Genomics, 15, 828.

Lole, K.S., Bollinger, R.C., Paranjape, R.S., Gadkari, D., Kulkarni, S.S., Novak, N.G., Ingersoll, R., Sheppard, H.W., \& Ray, S.C. (1999). Full-length human immunodeficiency virus type 1 genomes from subtype C-infected seroconverters in India, with evidence of intersubtype recombination. J Virol, $73,152-160$.

Martinez, M.A., Dopazo, J., Hernandez, J., Mateu, M.G., Sobrino, F., Domingo, E., \& Knowles, N.J. (1992). Evolution of the capsid protein genes of foot-and-mouth disease virus: antigenic variation without accumulation of amino acid substitutions over six decades. J Virol, 66, 3557-3565.

Martinez-Salas, E., \& Belsham, G.J. (2017). Genome organization, translation and replication of footand-mouth disease virus RNA. Chapter 2. pp13- 42. In: Foot-and-mouth disease: Current Research and Emerging Trends. Edited by: F. Sobrino and E. Domingo. Caister Academic Press, Norfolk, UK. ISBN: 978-1-910190-51-7.

Mason, P.W., Pacheco, J.M., Zhao, Q-Z., \& Knowles, N.J. (2003). Comparisons of the complete genomes of Asian, African and European isolates of a recent foot-and-mouth disease virus type $\mathrm{O}$ pandemic strain (PanAsia). J Gen Virol, 84, 1583-1593.

McCahon, D., Slade, W. R., Priston, K. A. J., \& Lake, J. R. (1977). An extended genetic recombination map for foot-and-mouth disease virus. J Gen Virol, 35, 555-565.

This article is protected by copyright. All rights reserved 
McIntyre, C.L., McWilliam Leitch, E.C., Savolainen-Kopra, C., Hovi, T., \& Simmonds, P. (2010). Analysis of genetic diversity and sites of recombination in human Rhinovirus species C. J Virol 84, 10297-10310. doi:10.1128/ JVI.00962-10.

Mohapatra, J.K., Sanyal, A., Hemadri, D., Tosh, C., Biswas, S., Knowles, N.J., Rasool, T.J., Bandyopashyay, S.K., \& Pattnaik, B. (2008). Comparative genomics of serotype Asia 1 foot-andmouth disease virus isolates from India sampled over the last two decades. Virus Res, 136, 16-29.

Nagendrakumar, S.B., Madhanmohan, M., Rangarajan, P.N., \& Srinivasan, V.A. (2009). Genetic analysis of foot-and-mouth disease virus serotype A of Indian origin and detection of positive selection and recombination in leader protease-and capsid-coding regions. J Biosci, 34, 85-101.

Oberste, M.S., Peñaranda, S., \& Pallansch, M.A. (2004). RNA recombination plays a major role in genomic change during circulation of Coxsackie B Viruses. J Virol, 78, 2948-2955. doi:10.1128/JVI.78.6.2948-2955.2004.

Paton, D.J., Sumption, K.J., \& Charleston, B. (2009). Options for control of foot-and-mouth disease: knowledge, capability and policy. Philos Trans R Soc Lond B Biol Sci. 364, 2657-2667.

Paton, D.J., Gubbins, S., \& King, D.P. (2018). Understanding the transmission of foot-and-mouth disease virus at different scales. Curr Opin Virol, 28, 85-91.

Sanger, F., Nicklen, S., \& Coulson, A.R. (1977). DNA sequencing with chain-terminating inhibitors. Proc Natl Acad Sci USA, 74, 5463-5467.

Sangula, A.K., Belsham, G.J., Muwanika, V.B., Heller, R., Balinda, S.N., \& Siegismund, H.R. (2010). Co-circulation of two extremely divergent serotype SAT 2 lineages in Kenya highlights challenges to foot-and-mouth disease control. Arch Virol, 155, 1625-1630.

Salt, J.S. (1993). The carrier state in foot-and-mouth disease-an immunological review. Br Vet J, 149, 207-223.

This article is protected by copyright. All rights reserved 
Simmonds, P., \& Welch, J. (2006). Frequency and dynamics of recombination within different species of human enteroviruses. J Virol, 80, 483-493. doi:10.1128/ JVI.80.1.483-493.2006.

Sutmoller, P., McVicar, J.W., \& Cottrall, G.E. (1968). The epizootiological importance of foot-andmouth disease carriers. Arch Ges Virusforsch, 23, 227-235.

Tamura, K., \& Nei, M. (1993). Estimation of the number of nucleotide substitutions in the control region of mitochondrial DNA in humans and chimpanzees. Mol Biol Evol. 10, 512-526.

Tully, D.C., \& Fares, M.A. (2008). The tale of a modern animal plague: tracing the evolutionary history and determining the time-scale for foot and mouth disease virus. Virology, 382, 250-256.

Valdazo-Gonzalez, B., Polihronova, L., Alexandrov, T., Normann, P., Knowles, N.J., Hammond, J.M., Georgiev, G.K., Ozyoruk, F., Sumption, K.J., Belsham, G.J., \& King, D.P. (2012). Reconstruction of the transmission history of RNA virus outbreaks using full genome sequences: foot-and-mouth disease virus in Bulgaria in 2011. PLoS One 7, e49650. doi: 10.1371/journal.pone.0049650.

Villaverde, A., Martinez, M.A., Sobrino, F., Dopazo, J., Moya, A., \& Domingo, E. (1991). Fixation of mutations at the VP1 gene of foot-and-mouth disease virus. Can quasispecies define a transient molecular clock? Gene, 103, 147-153.

Waheed, U., Parida, S., Khan, Q.M., Hussain, M., Ebert, K., Wadsworth, J., Reid, S.M., Hutchings, G.H., Mahapatra, M., King, D.P., Paton, D.J., \& Knowles, N.J. (2011). Molecular characterisation of foot-and-mouth disease viruses from Pakistan, 2005-2008. Transbound Emerg Dis 58, 166-17,2.

Woodbury, E.L. (1995). A review of the possible mechanisms for the persistence of foot-and-mouth disease virus. Epidemiol Infect, 114, 1-13.

Xu, L., Hurtle, W., Rowland, J.M., Casteran, K.A., Bucko, S.M., Grau, F.R., Valdazo-Gonzalez, B., Knowles, N.J., King, D.P., Beckham, T.R., \& McIntosh, M.T. (2013). Development of a universal RT-PCR for amplifying and sequencing the leader and capsid-coding region of foot-and-mouth disease virus. J Virol Methods, 189, 70-76.

This article is protected by copyright. All rights reserved 
Yoon, S.H., Lee, K.N., Park, J.H., \& Kim, H. (2011)., Molecular epidemiology of foot-and-mouth disease virus serotypes $\mathrm{A}$ and $\mathrm{O}$ with emphasis on Korean isolates: temporal and spatial dynamics. Arch Virol, 156, 817-826.

Zhang, X., Liu, Z., Zhao, Q., Chang, H., \& Xie, Q. (2004). Sequencing and analysis for the full-length genome RNA of foot-and-mouth disease virus China/99. Sci. China, C, Life Sci. 47, 74-81

This article is protected by copyright. All rights reserved 


\section{Figure legends}

Figure 1. Maximum likelihood phylogenetic trees constructed using (a) VP1 coding nucleotide sequences and (b) VP4 coding sequences. Serotypes O, A and Asia-1 FMDVs have been indicated with black, turquoise and green lines, respectively. The locations of three FMDVs belonging to Group-VII (Sindh-08) of serotype Asia-1 in the trees are shown with filled green circles. Only bootstrap values $\geq 70 \%$ are shown.

Figure 2. Maximum likelihood phylogenetic trees constructed using (a) capsid coding region (P1), (b) partial 5'-UTR sequences, (c) Leader protease (L ${ }^{\text {pro }}$ ) coding region, (d) P2 coding region, (e) 3A and (f) 3BCD coding sequences of serotypes $\mathrm{O}$ (shown with black lines), A (shown with turquoise lines) and Asia-1 (shown with green lines) FMDVs. Only bootstrap values $\geq 70 \%$ are shown.

Figure 3. Recombination analysis of $\mathrm{O} / \mathrm{BUL} / 1 / 2010$ and $\mathrm{A} / \mathrm{TUR} / 11 / 2013$. Panel A shows the mosaic structure of O/BUL/1/2010, whereas, panel B shows the chimeric genome of A/TUR/11/2013.

Figure 4. Recombination analysis of serotype Asia-1 FMDVs. Panel (A) shows that As/BAM/AFG/L590/2009 is a recombinant virus. Panel (B) shows the mosaic structure of As/PAK/30/2002.

This article is protected by copyright. All rights reserved 
Table 1. Details of the foot-and-mouth disease viruses used in the present study

\begin{tabular}{|c|c|c|c|c|c|}
\hline Serotype & $\begin{array}{l}\text { Country of } \\
\text { origin }\end{array}$ & Name & $\begin{array}{l}\text { Genomic } \\
\text { region* }\end{array}$ & $\begin{array}{l}\text { Accession } \\
\text { number }\end{array}$ & Reference \\
\hline $\mathrm{O}$ & Afghanistan & As/BAM/AFG/L590/2009 & Near CG & HQ113233 & Belsham et al., 2011 \\
\hline $\mathrm{O}$ & Afghanistan & O/KAB/AFG/LI-709/2009 & Near CG & MN062578 & This study \\
\hline $\mathrm{O}$ & Afghanistan & O/AFG/16/2003 & 5'-UTR & HQ268526 & Xu et al., 2013 \\
\hline & & & $+\mathrm{L}+\mathrm{P} 1$ & & \\
\hline $\mathrm{O}$ & Bulgaria & $\mathrm{O} / \mathrm{BUL} / 1 / 2010$ & $\mathrm{CG}$ & JX040485 & Valdazo-Gonzalez et al., 2012 \\
\hline $\mathrm{O}$ & Bulgaria & 12LPN1 & CG & JX066664 & Valdazo-Gonzalez et al., 2012 \\
\hline $\mathrm{O}$ & Bulgaria & 12LPN3 & $\mathrm{CG}$ & JX066665 & Valdazo-Gonzalez et al., 2012 \\
\hline $\mathrm{O}$ & Bulgaria & BUL/11/2011 & $\mathrm{CG}$ & JX040486 & Valdazo-Gonzalez et al., 2012 \\
\hline $\mathrm{O}$ & Bulgaria & O/BUL/20/2011 & $\mathrm{CG}$ & JX040487 & Valdazo-Gonzalez et al., 2012 \\
\hline $\mathrm{O}$ & Bulgaria & O/BUL/26/2011 & $\mathrm{CG}$ & JX040488 & Valdazo-Gonzalez et al., 2012 \\
\hline $\mathrm{O}$ & Bulgaria & O/BUL/30/2011 & $\mathrm{CG}$ & JX040489 & Valdazo-Gonzalez et al., 2012 \\
\hline $\mathrm{O}$ & Bulgaria & O/BUL/32/2011 & $\mathrm{CG}$ & JX040490 & Valdazo-Gonzalez et al., 2012 \\
\hline $\mathrm{O}$ & China & O/CHA/1/99_(Tibet) & $\mathrm{CG}$ & AF506822 & Zhang et al., 2004 \\
\hline $\mathrm{O}$ & Iran & O/IRN_073/2001 & $\mathrm{CG}$ & JF749851 & Xu et al., 2013 \\
\hline $\mathrm{O}$ & Iran & O/KHO/IRN/L1/2010 & Near CG & MN062579 & This study \\
\hline $\mathrm{O}$ & Iran & O/KHO/IRN/L5/2010 & Near CG & MN062580 & This study \\
\hline $\mathrm{O}$ & Iran & O/IRAN/1/2010 & $\mathrm{P} 1$ & HQ663879 & Unpublished \\
\hline & & & $3 \mathrm{~A}-3 \mathrm{~B}$ & JN652665 & \\
\hline $\mathrm{O}$ & Israel & $\mathrm{O} / \mathrm{ISR} / 2 / 2011$ & $\mathrm{CG}$ & JX040501 & Valdazo-Gonzalez et al., 2012 \\
\hline $\mathrm{O}$ & Israel & O/Israel/2007 & $\mathrm{CG}$ & FJ175661 & Xu et al. (unpublished) \\
\hline $\mathrm{O}$ & Israel & O/Israel/2007 & $\mathrm{CG}$ & FJ175666 & Xu et al. (unpublished) \\
\hline $\mathrm{O}$ & Japan & O/JPN/2000 & Near CG & AB079061 & Kanno et al., 2002 \\
\hline $\mathrm{O}$ & Pakistan & O/PAK/10/2016 & $\mathrm{CG}$ & MH784403 & Bachanek-Bankowska et al., 2019 \\
\hline $\mathrm{O}$ & Pakistan & $\mathrm{O} / \mathrm{PAK} / 4 / 2017$ & $\mathrm{CG}$ & MH784404 & Bachanek-Bankowska et al., 2019 \\
\hline $\mathrm{O}$ & Pakistan & O/PAK/14/2017 & $\mathrm{CG}$ & MH784405 & Bachanek-Bankowska et al., 2019 \\
\hline $\mathrm{O}$ & Pakistan & O/Nari/UVAS-Pak/2005 & CG & KT003716 & Shabbir and Munir, 2015 \\
\hline $\mathrm{O}$ & Pakistan & O/PAK/45/2008 & CG & GU384683 & Xu et al., 2013 \\
\hline $\mathrm{O}$ & Pakistan & O/ISL/PAK/L1573/2009 & Near CG & HQ113232 & Belsham et al., 2011 \\
\hline $\mathrm{O}$ & Pakistan & O/PAK/44/2008 & $\mathrm{CG}$ & GU384682 & Xu et al., 2013 \\
\hline $\mathrm{O}$ & Pakistan & O/PUN/PAK/L1358/2008 & Near CG & MN062581 & This study \\
\hline $\mathrm{O}$ & Pakistan & O/PUN/PAK/L1370/2009 & Near CG & MN062582 & This study \\
\hline $\mathrm{O}$ & Pakistan & O/ISL/PAK/L1412/2009 & Near CG & MN062583 & This study \\
\hline $\mathrm{O}$ & Pakistan & O/NWF/PAK/L1417/2009 & Near CG & MN062584 & This study \\
\hline $\mathrm{O}$ & Pakistan & O/PAK/10/2005 & L-P1 & JF749855 & Xu et al., 2013 \\
\hline $\mathrm{O}$ & Pakistan & O/PAK/29/2008 & L-P1 & GU384684 & Xu et al., 2013 \\
\hline $\mathrm{O}$ & Pakistan & O/PAK/70/2008 & L-P1 & JF749846 & Xu et al., 2013 \\
\hline $\mathrm{O}$ & Saudi Arabia & $\mathrm{O} / \mathrm{SAU} / 4 / 2005$ & L-P1 & JF749856 & Xu et al., 2013 \\
\hline
\end{tabular}




\begin{tabular}{|c|c|c|c|c|c|}
\hline $\mathrm{O}$ & Taiwan & O/TAW/2/99 (BOV) & CG & AJ539137 & Mason et al., 2003 \\
\hline $\mathrm{O}$ & Turkey & O1/Manisa/iso87_ & CG & AY593823 & Carrillo et al., 2005 \\
\hline $\mathrm{O}$ & Turkey & O/TUR/12/2013 & CG & KM268895 & Logan et al., 2014 \\
\hline $\mathrm{O}$ & Turkey & O/TUR/18/2010 & $\mathrm{CG}$ & JX040491 & Valdazo-Gonzalez et al., 2012 \\
\hline $\mathrm{O}$ & Turkey & O/TUR/840/2010 & CG & JX040493 & Valdazo-Gonzalez et al., 2012 \\
\hline $\mathrm{O}$ & Turkey & O/TUR/868/2010 & $\mathrm{CG}$ & JX040494 & Valdazo-Gonzalez et al., 2012 \\
\hline $\mathrm{O}$ & Turkey & O/TUR/883/2010 & $\mathrm{CG}$ & JX040495 & Valdazo-Gonzalez et al., 2012 \\
\hline $\mathrm{O}$ & Turkey & O/TUR/926/2010 & CG & JX040496 & Valdazo-Gonzalez et al., 2012 \\
\hline $\mathrm{O}$ & Turkey & O/TUR/1003/2010 & $\mathrm{CG}$ & JX040497 & Valdazo-Gonzalez et al., 2012 \\
\hline $\mathrm{O}$ & Turkey & O/TUR/36/2010 & CG & JX040492 & Valdazo-Gonzalez et al., 2012 \\
\hline $\mathrm{O}$ & Turkey & O/TUR/1086/2010 & CG & JX040498 & Valdazo-Gonzalez et al., 2012 \\
\hline $\mathrm{O}$ & Turkey & O/TUR/8/2011 & CG & JX040499 & Valdazo-Gonzalez et al., 2012 \\
\hline $\mathrm{O}$ & Turkey & O/TUR/27/2011 & CG & JX040500 & Valdazo-Gonzalez et al., 2012 \\
\hline $\mathrm{O}$ & Turkey & O/TUR/1112/2010 & CG & MN062585 & This study \\
\hline $\mathrm{O}$ & Turkey & O/TUR/164/2009 & P1 & MN056182 & This study \\
\hline $\mathrm{O}$ & Turkey & O/TUR/290/2008 & $\mathrm{P} 1$ & MN062577 & This study \\
\hline $\mathrm{O}$ & United & $\mathrm{O} / \mathrm{UKG} / 35 / 2001$ & $\mathrm{CG}$ & AJ539141 & Mason et al., 2003 \\
\hline & Kingdom & & & & \\
\hline A & Afghanistan & A/BAD/AFG/L2813/2009 & Near CG & MN062586 & This study \\
\hline A & Afghanistan & A/AFG/1120/2005 & L-P1 & JF749844 & Xu et al., 2013 \\
\hline A & Afghanistan & A/KUN/AFG/L1495/2009 & $\mathrm{P} 1$ & JF721440 & Jamal et al., 2011a \\
\hline A & Iran & A/IRN/2005 & Near CG & EF494486 & Klein et al. (unpublished) \\
\hline A & Iraq & A22/IRQ/24/64 & $\mathrm{CG}$ & AY593763 & Carrillo et al., 2005 \\
\hline A & Pakistan & A/Hafizabad/QOL-UVAS- & $\mathrm{CG}$ & KY446902 & Unpublished \\
\hline & & $\mathrm{Pak} / 2005$ & & & \\
\hline A & Pakistan & A/PAK/1/2006 & Near CG & EF494487 & Klein et al. (unpublished) \\
\hline A & Pakistan & $\mathrm{A} / \mathrm{PAK} / 3 / 2006$ & Near CG & EF117837 & Klein et al (unpublished) \\
\hline A & Pakistan & A/PAK/5/2006 & Near CG & EF494488 & Klein et al (unpublished) \\
\hline A & Pakistan & A/SIN/PAK/L4/2008 & Near CG & JN006722 & Jamal et al., 2011a \\
\hline A & Pakistan & A/SIN/PAK/L693/2009 & Near CG & MN062587 & This study \\
\hline A & Pakistan & A/PAK/76/2009 & L-P1 & GU384686 & Xu et al., 2013 \\
\hline A & Saudi Arabia & A/SAU/1/2015 & $\mathrm{CG}$ & KU127247 & Bachanek-Bankowska et al., 2016 \\
\hline A & Turkey & A/TUR_004/2003 & & JF749848 & Xu et al., 2013 \\
\hline A & Turkey & A/A28/TUR/iso44 (1972) & $\mathrm{CG}$ & AY593772 & Carrillo et al., 2005 \\
\hline A & Turkey & A/TUR/11/2013 & $\mathrm{CG}$ & KM268896 & Logan et al., 2014 \\
\hline A & Turkey & A/TUR/2006 & Near CG & JF749841 & Xu et al., 2013 \\
\hline Asia-1 & Afghanistan & As/BAM/AFG/L590/2009 & Near CG & HQ113233 & Belsham et al., 2011 \\
\hline Asia-1 & Bangladesh & As/BAN/TA/Ma-167/2013 & $\mathrm{CG}$ & MF782478 & Unpublished \\
\hline Asia-1 & China & As/HKN/CHA/05 & CG & EF149010 & Li et al., 2007 \\
\hline
\end{tabular}




\begin{tabular}{llllll} 
Asia-1 & India & As/IND/82-96 & CG & DQ989309 & Mohapatra et al., 2008 \\
Asia-1 & India & As/IND/148/01 & CG & DQ989317 & Mohapatra et al., 2008 \\
Asia-1 & Iran & As/IRN/31/2004 & L-P1 & HQ268516 & Xu et al., 2013 \\
Asia-1 & Israel & As/ISRL/3/63 & CG & AY593796 & Carrillo et al., 2005 \\
Asia-1 & Lebanon & As/Leb/1/83 & CG & AY593799 & Carrillo et al., 2005 \\
Asia-1 & Pakistan & As/Mazbi/QOL-UVAS- & CG & KY446901 & Shabbir (unpublished) \\
& & Pak/2006 & & & \\
Asia-1 & Pakistan & As/PAK_030/2002 & Near CG & JF749849 & Xu et al., 2013 \\
Asia-1 & Pakistan & As/PAK/1/2004 & L+P1 & HQ268513 & Xu et al., 2013 \\
Asia-1 & Pakistan & As/PAK/1/54 & CG & AY593795 & Carrillo et al., 2005 \\
Asia-1 & Pakistan & As/SIN/PAK/L5/2008 & Near CG & JN006719 & Jamal et al., 2011b \\
Asia-1 & Pakistan & As/SIN/PAK/L2810/2009 & Near CG & JN006720 & Jamal et al., 2011b \\
Asia-1 & Pakistan & As/Pak/69/2003 & L+P1 & HQ268514 & Xu et al., 2013 \\
Asia-1 & Turkey & As/TUR/13/2013 & CG & KM268898 & Logan et al., 2014 \\
Asia-1 & Turkey & As/Shamir/89 & CG & JF739177 & Lee et al., unpublished \\
\hline
\end{tabular}

$\mathrm{CG}=$ complete genome 
a)

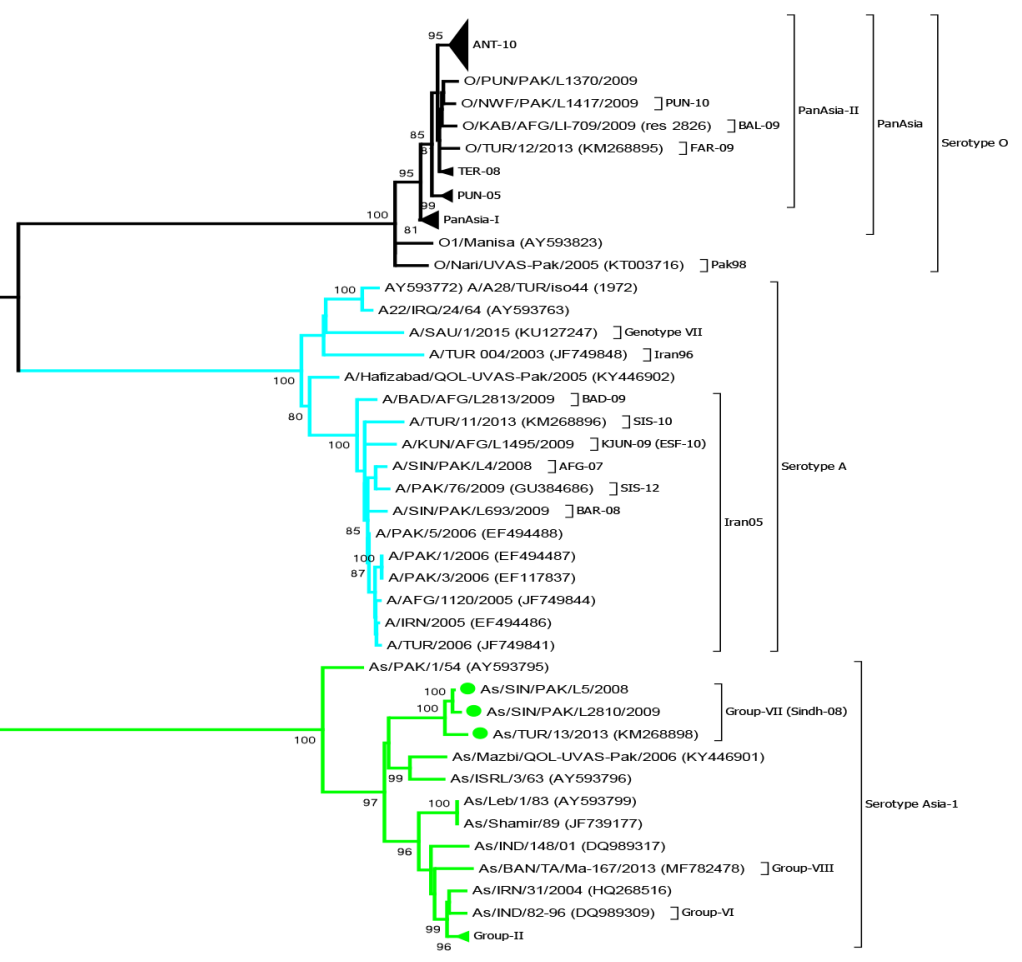

b)

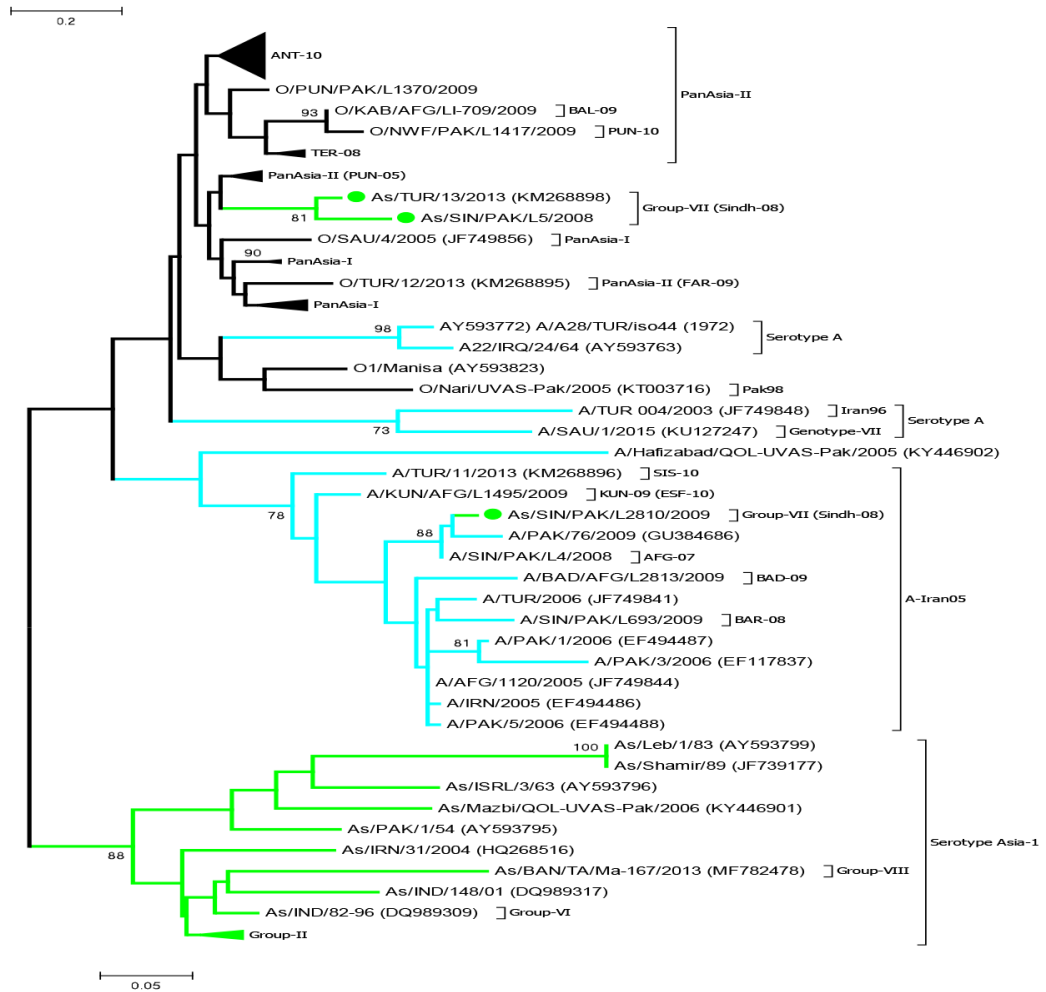

tbed_13433_f1.tif 

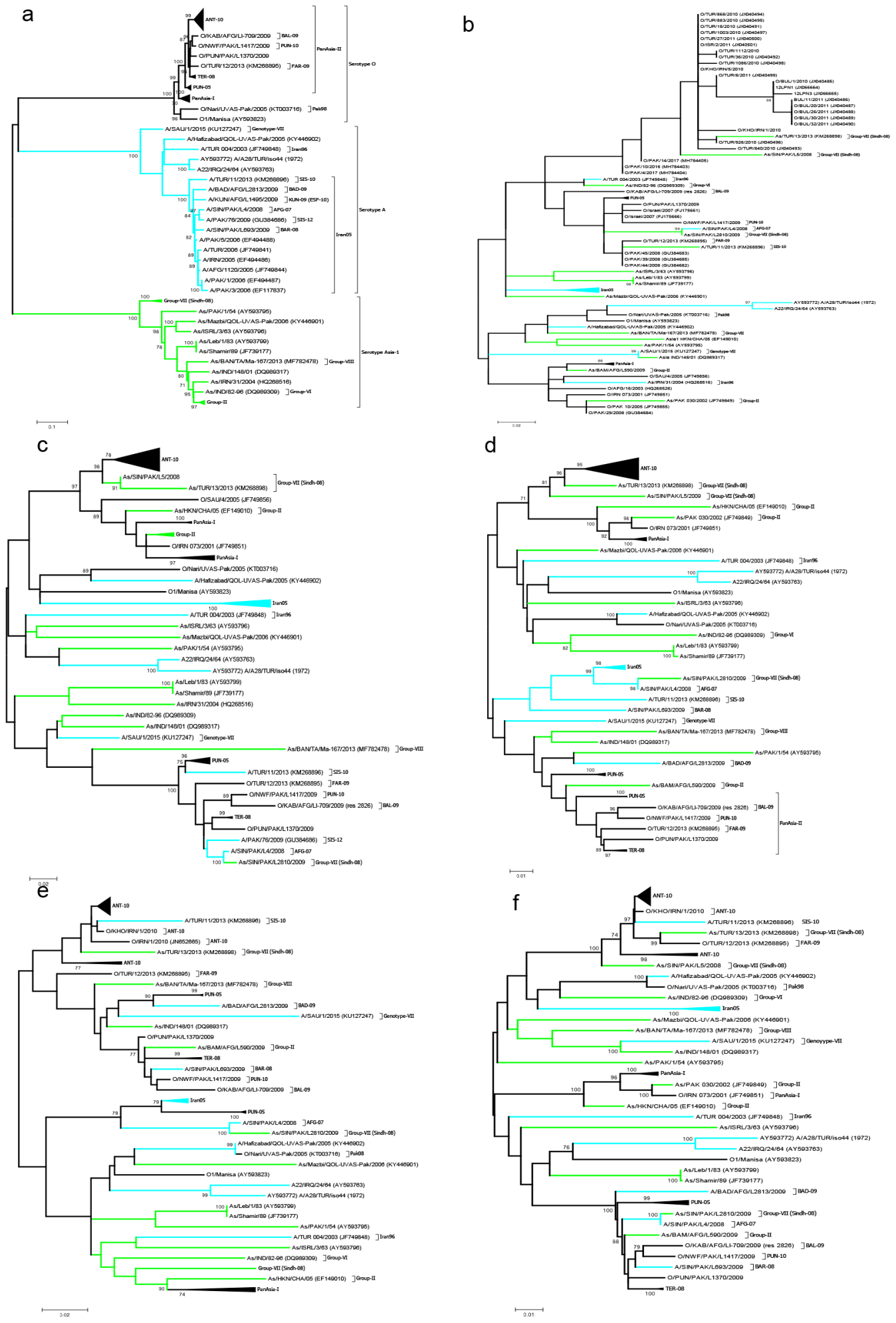

tbed_13433_f2.tif 


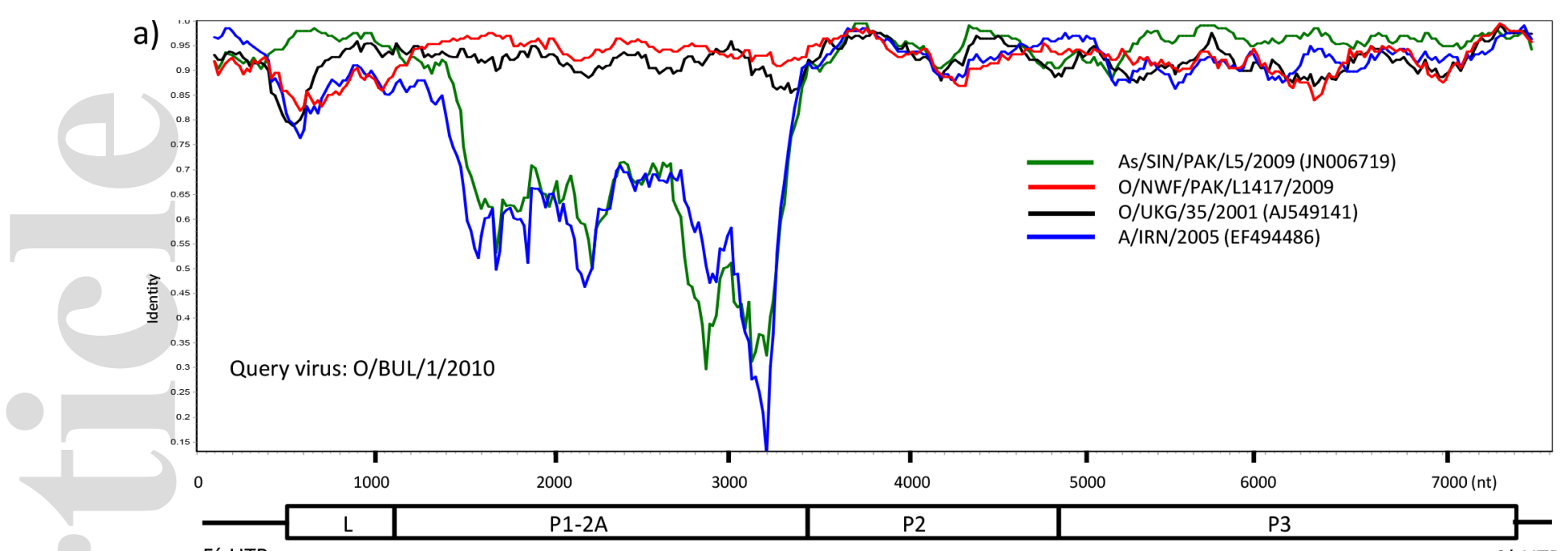

b)

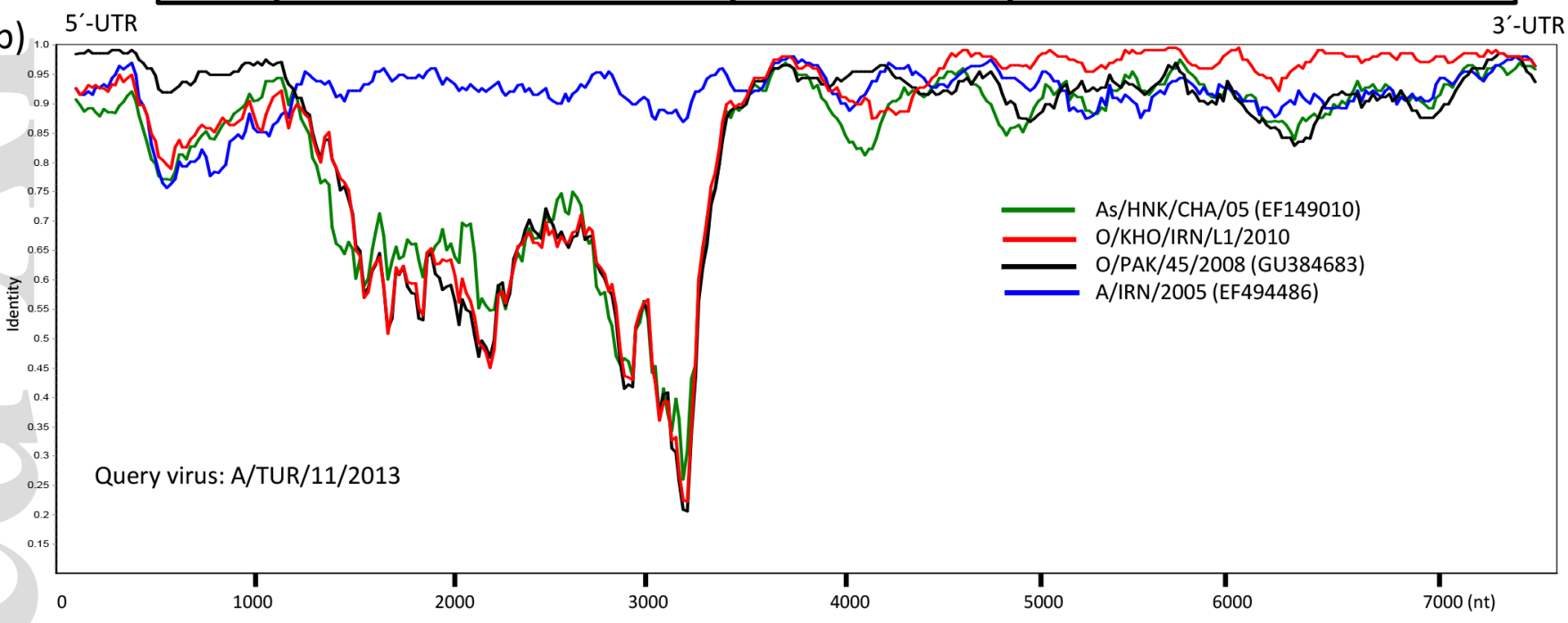

tbed_13433_f3.tif

This article is protected by copyright. All rights reserved 

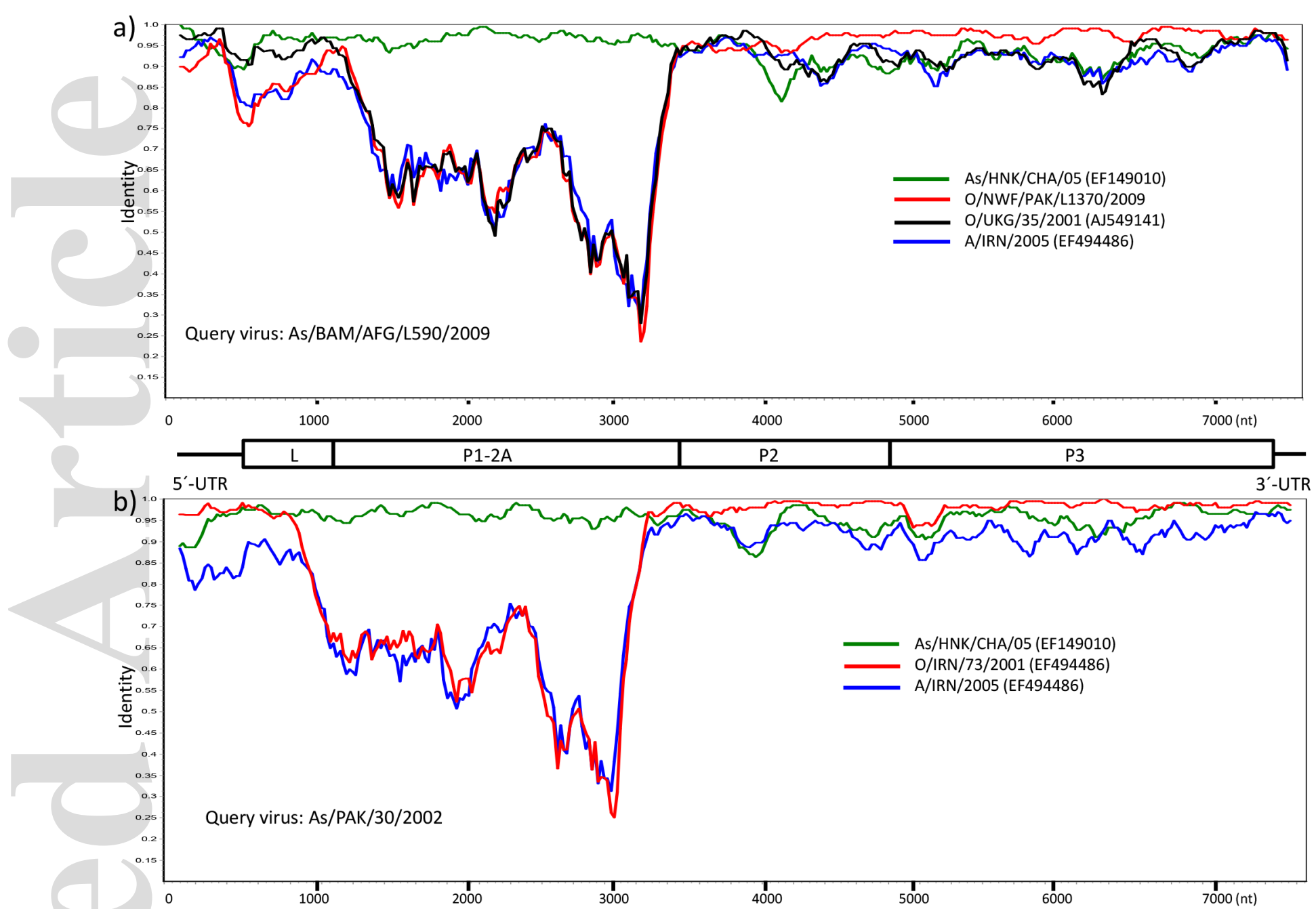

tbed_13433_f4.tif

This article is protected by copyright. All rights reserved 